\title{
As responsabilidades do editor de um periódico científico
}

$\mathrm{A}$ instituição da avaliação dos veículos nos quais se expressa a produção científica dos pesquisadores envolvidos no sistema nacional de pós-graduação pela CAPES e, no caso específico da área da Psicologia, o trabalho realizado pela comissão conjunta CAPES/ANPEPP, em que pese aos problemas inerentes a empreendimentos dessa natureza, teve como um de seus diversos efeitos ${ }^{1}$, a preocupação dos editores com a qualificação dos periódicos sob sua responsabilidade.

Esta preocupação pode ser aquilatada pelo aumento do interesse dos editores nos eventos voltados para o campo da informação - como aqueles promovidos pela Associação Brasileira de Editores Científicos (ABEC), expondo os periódicos, criando listas de discussão, enfim, multiplicando oportunidades de troca de experiências, buscando romper o isolamento que nos caracterizava.

Não parece desarrazoado supor que os editores da área, como regra, são pesquisadores que passam a se envolver na atividade de editoração como uma atividade paralela, muitas vezes, por circunstâncias fortuitas, sem reunir, de início, as condições/conhecimentos que seriam desejáveis para assumir tal responsabilidade.

Quantos de nós nos introduzimos nesse empreendimento pensando que produzir uma revista científica significaria, simplesmente, colecionar e organizar um conjunto de artigos e entregar a uma editora? É evidente que se trata de uma caricatura: o ponto é a qualificação como pesquisador e produtor de conhecimento como uma condição importante para qualificá-lo como editor de um periódico especializado da área mas, lamentavelmente, insuficiente.

Essas reflexões foram motivadas, na realidade, por algumas interpelações de editores e pesquisadores de diversas instituições brasileiras interessados na atividade de editoração, acerca das responsabilidades do editor.

Trata-se de uma matéria polêmica, objeto de estudos no campo das Ciências da Informação, que trato aqui apenas de forma alusiva.

É importante lembrar que a área da Psicologia já produziu reflexões extremamente interessantes sobre a questão. A série de editoriais publicada, anos atrás, pela revista Psicologia: Teoria e Pesquisa, assinada pela então editora Maria Angela Guimarães Feitosa, constitui-se em material de leitura obrigatória para todos aqueles que têm interesse nesse campo.
Em um deles, a editora trata especificamente da responsabilidade ética do editor de um periódico científico (Feitosa, 1994a $)^{2}$. Feitosa divide as responsabilidades em três grupos. O primeiro diz respeito à responsabilidade social, remetendo às funções de documentação científica e de disseminação do conhecimento, inerentes à atividade editorial. $\mathrm{O}$ segundo engloba a responsabilidade com as normas editoriais - as operacionais (e.g., limites de tamanho, formatação), as referentes à tramitação interna (e.g., revisão por pares) e as relativas ao escopo da revista (e.g., política editorial). No terceiro, Feitosa apresenta um conjunto de questões que se apresentam ao editor no trabalho cotidiano: o tratamento eqüânime dos manuscritos, a isenção na seleção dos consultores, o cuidado ao não tramitar material sem a expressa autorização dos autores, a oportunidade de o editor publicar na revista que dirige, entre outras.

Em outro trabalho, no campo das ciências da informação, Rosaly Fávero (2001) arrola cinco responsabilidades principais do editor, que seriam (a) direção do processo de publicação e a responsabilidade pela manutenção da qualidade científica; (b) avaliação confidencial, objetiva e sem preconceito dos manuscritos no menor período de tempo possível; (c) isenção na escolha dos revisores (sem visar resultados previsíveis); (d) proteção dos direitos dos autores e revisores, promovendo uma comunicação objetiva e profissional entre eles; e (e) decisão final sobre a aceitação ou rejeição de um manuscrito.

A própria $\mathrm{ABEC}$ esboçou uma proposta de Código de Ética para garantir a integridade e a lisura da pesquisa e publicação dos seus resultados (Pessanha, 2001). No capítulo referente ao editor, o Código estabelece, resumidamente, (a) a responsabilidade de tomar decisões sobre os manuscritos com base em critérios objetivos e científicos, com presteza; (b) a proteção aos direitos dos autores e avaliadores; (c) a isenção na seleção dos consultores; (d) a responsabilidade pelo sigilo dos originais e imparcialidade no processo de avaliação; (e) a responsabilidade final, de forma judiciosa, pelo que é publicado na revista.

$\mathrm{Na}$ realidade, pelos poucos exemplos, é possível depreender que a polêmica não reside tanto no rol de responsabilidades, quanto na forma de colocá-las em prática.

Como garantir o sigilo na tramitação dos manuscritos, em uma comunidade científica reduzida como a da Psicologia no Brasil? Como garantir que os consultores 
produzam avaliações imparciais, cuidadosas e (importante!) sejam pontuais? Como garantir que o material que nos foi confiado tenha tramitação rápida e seja publicado antes que os dados tratados se desatualizem?

No capítulo dos dilemas do editor científico brasileiro na área da Psicologia, certamente figuram, além dessas preocupações, a responsabilidade de organizar uma equipe competente e disponível para as tarefas de editoração; de estruturar seu tempo para que tal atividade não o impeça de permanecer, ele próprio, um produtor de conhecimento; de garantir o correto cumprimento dos padrões e prazos pelas editoras e gráficas responsáveis; e de buscar financiamento para viabilizar a produção.

Certamente, não são poucos os desafios - a complexidade da tarefa editorial somente engrandece os esforços daqueles que estão empenhados nessa árdua responsabilidade.

A proposta, finalizando estas breves considerações, é recolocar o convite feito por Feitosa (1994a) nas suas Considerações Finais, para que aprofundemos nossas reflexões sobre as responsabilidades de um periódico científico, para que possamos, tanto no aspecto ético - objeto privilegiado da análise da autora -, quanto nos demais, "consolidar princípios que norteiem com segurança nossos procedimentos" (p. viii).

Esta fascículo que ora se apresenta ao público, embora corresponda ao número 1 do volume 7, é o segundo que é publicado em 2002. Antes dele, lançamos o número especial temático, sobre Psicologia Organizacional e do Trabalho, organizada por Jairo E. Borges-Andrade e José Carlos Zanelli, editores-convidados.

Os leitores irão notar, também, o substancial aumento do número de artigos deste fascículo, decorrente da necessidade da manutenção de um fluxo submissão-publicação dentro de limites aceitáveis. Desta forma, contamos com dezoito artigos, 14 na seção regular de artigos e 4 no Dossiê "Brincar para quê? Uma abordagem etológica ao estudo da brincadeira".

$\mathrm{Na}$ expectativa de que este fascículo seja do agrado de todos, aprovitamos para agradecer aos nossos colaboradores e aos leitores, que têm tornado Estudos de Psicologia uma das referências da Psicologia do Brasil.

\section{Oswaldo H. Yamamoto}

Editor

\section{Referências}

Fávero, R. (2001). Política editorial e administração de revistas científicas e culturais. In Associação Brasileira de Editores Científicos [ABEC] (Org.), X Curso de Editoração Científica (pp. 26-35). Atibaia: Autor.

Feitosa, M. A. G. (1993). A ética no processo de revisão de manuscritos: a expectativa do editor em relação ao papel do consultor. Psicologia: Teoria e Pesquisa, 9, iv-vi.

Feitosa, M. A. G. (1994a). A responsabilidade ética do editor de um periódico científico. Psicologia: Teoria e Pesquisa, 10, iv-vii.

Feitosa, M. A. G. (1994b). A responsabilidade ética do autor de manuscritos submetidos a publicação. Psicologia: Teoria e Pesquisa, 10, iv-vii.

Pessanha, C. (2001). Critérios editoriais de avaliação científica. In Associação Brasileira de Editores Científicos [ABEC] (Org.), X Curso de Editoração Científica (pp. 46-51). Atibaia: Autor.

Notas

1 No Editorial da edição 6.2, do ano de 2001, tivemos a oportunidade de enumerar alguns dados que indicam o impressionante aprimoramento dos periódicos da área da Psicologia.

2 Os demais, que na realidade precedem este aqui referido, tratam da ética no processamento do material da revista (Feitosa, 1993) e do autor na submissão de um manuscrito (Feitosa, 1994b). 